\title{
HUBUNGAN KUALITAS TIDUR DAN TIPE KEPRIBADIAN DENGAN TEKANAN DARAH PADA PASIEN HIPERTENSI DI UPT GRIYA ANTAPANI KOTA BANDUNG TAHUN 2017
}

\author{
Jahidul Fikri Amrullah ${ }^{1}$, Meiga Murti ${ }^{2}$ \\ jasielfa@yahoo.com \\ ${ }^{1,2}$ Program Studi Sarjana Keperawatan STIKes Dharma Husada Bandung
}

\begin{abstract}
ABSTRAK
Hipertensi saat ini merupakan penyakit yang prevalensinya tinggi, prevalensi hipertensi di seluruh dunia sekitar $972(26,4 \%)$ juta orang. Hipertensi merupakan penyebab kematian peringkat ketiga di Indonesia. Angka kejadian hipertensi di Jawa Barat sebanyak 29,4\% dan di Bandung sebanyak $12,10 \%$. Efek dari hipertensi adalah serangan jantung, stroke, gagal ginjal sampai kematian mendadak. Hipertensi dapat dipengaruhi berbagai faktor diantaranya kualitas tidur dan tipe kepribadian. Penelitian ini bertujuan untuk mengetahui hubungan kualitas tidur dan tipe kepribadian dengan tekanan darah pada pasien hipertensi di UPT Griya Antapani Kota Bandung. Jenis penelitian ini adalah kuantitatif dengan pendekatan cross sectional. Sampel dalam penelitian ini berjumlah 54 responden yang sesuai dengan kriteria inklusi dan eksklusi. Teknik pengambilan sampel menggunakan purposive sampling. Pengukuran kualitas tidur menggunakan kuesioner PSQI, untuk tipe kepribadian dibagi menjadi kepribadian tipe A dan B yang dikembangkan dari teori tipe kepribadian A dan B Friedman dan Rosenman.

Analisis data pada penelitian ini menggunakan uji chi square. Hasil penelitian menunjukan sebagian besar atau 28 orang $(51,9 \%)$ mengalami hipertensi sedang,hampir seluruh atau 42 orang $(77,8 \%)$ mengalami kualitas tidur buruk,sebagian besar atau 28 orang $(51,9 \%)$ memiliki kepribadian tipe A, ada hubungan kualitas tidur dan tekanan darah dengan p value $(0,000)<a(0,05)$, ada hubungan tipe kepribadian dan tekanan darah dengan $\mathrm{p}$ value $(0,000)<a(0,05)$. Kesimpulan dari penelitian ini adalah terdapat hubungan kualitas tidur dan tipe kepribadian dengan tekanan darah pada pasien hipertensi di UPT Griya Antapani Kota Bandung. Penelitian ini diharapkan dapat dijadikan sebagai dasar untuk memberikan intervensi kepada pasien yang mengalami gangguan tidur dan pasien dengan kepribadian tipe A agar tidak meningkatkan derajat hipertensi.
\end{abstract}

Kata Kunci: kualitas tidur, tipe kepribadian, hipertensi

PENDAHULUAN

Hipertensi merupakan masalah kesehatan dengan prevalensi yang tinggi di Indonesia, yaitu sebesar 25,8\% (Riskesdas, 2013). Data Riskesdas tahun 2010 juga menyebutkan hipertensi sebagai penyebab kematian nomor tiga setelah stroke dan tuberkolosis, jumlahnya mencapai 6,8\% dari proporsi penyebab kematian pada semua umur di Indonesia (Depkes, 2010). Di Indonesia, pada usia $\geq 18$ tahun didapatkan prevalensi tekanan darah tinggi sebesar $31,7 \%$, yang sudah mengetahui memiliki tekanan darah tinggi hanya 7,2\% dan yang minum obat hipertensi hanya 0,4\% (Depkes RI, 2012 dalam Magfirah, 2016).

Komplikasi hipertensi menyebabkan terjadinya payah jantung, gangguan pada ginjal, dan kebutaan. Dari hasil penelitian diketahui bahwa hipertensi dapat mengecilkan volume otak, sehingga 
mengakibatkan penurunan kemampuan fungsi kognitif dan intelektual. Yang paling parah adalah efek jangka panjang yang berupa kematian mendadak (Sustrani, 2004 dalam Norma Risnasari, 2012).

Beberapa hal yang dapat memicu tekanan darah tinggi adalah ketegangan, kekhawatiran, status sosial, kebisingan, gangguan, dan kegelisahan. Pengendalian pengaruh dan emosi negative tersebut tergantung juga pada kepribadian masingmasing individu. Hipertensi dapat dipengaruhi oleh gaya hidup (merokok, minum alkohol), stress, obesitas (kegemukan), kurang olahraga, kualitas tidur, keturunan, dan tipe kepribadian (Wolf, 2006 dalam Septiyani, 2010).

Kepribadian adalah sesuatu yang memberi tata tertib dan keharmonisan terhadap segala macam tingkah laku berbeda-beda yang dilakukan individu. Perbedaan faktor individu (kepribadian) mempengaruhi perilaku dan gaya hidup. Hal-hal tersebut mempengaruhi tingkat atau derajat hipertensi pasien. Tipe kepribadian berpengaruh terhadap kekambuhan hipertensi karena dilihat dari cara seseorang menggunakan koping stressnya (Calvin S. Hall \& Gardner Lindzey, 2000 dalam Septiyani, 2010).

Penelitian yang dilakukan oleh Ray Rosenman \& Meyer Friedman, dua orang ilmuan kardiologi, menunjukkan bahwa ada kaitan erat antara tipe kepribadian yang berdasarkan pola perilaku yaitu tipe A dan tipe $B$ dengan penyakit kardiovaskuler. Menurut Rosenman dan Friedman, kepribadian tipe A memiliki ciri-ciri, sebagai berikut: memiliki tingkat kesabaran rendah, tergesa-gesa dalam melakukan segala sesuatu, memiliki harapan yang tinggi untuk mencapai kesuksesan, memiliki keinginan yang tinggi untuk bersaing, agresif, dan mudah marah. Kepribadian tipe B memiliki ciriciri, sebagai berikut: memiliki tingkat kesabaran yang tinggi, santai dalam melakukan segala sesuatu, memiliki harapan yang rendah untuk mencapai kesuksesan, memiliki keinginan yang rendah untuk bersaing, kurang agresif, dan tidak mudah marah (Wolf, 2006 dalam Septiyani, 2010).

Dari hasil studi pendahuluan yang dilakukan pada tanggal 16 Desember 2016 di wilayah kerja Puskesmas Griya Antapani dengan teknik wawancara kepada 10 orang pasien hipertensi, didapatkan bahwa 5 dari 10 orang memiliki derajat hipertensi sedang dan 5 lainnya memiliki derajat hipertensi ringan. 6 orang pasien hipertensi mengatakan terburu-buru dalam melakukan aktivitas, 4 orang mengatakan dalam menunggu sesuatu suka tidak sabar, 3 orang mengatakan memiliki daya saing yang tinggi, 3 orang mengatakan suka melakukan sesuatu dengan memaksakan 
diri, 3 orang mengatakan sering melakukan 2 hal dalam waktu yang bersamaan, 3 orang mengatakan selalu ingin memiliki hasil terbaik dalam melakukan sesuatu dan 3 orang mengatakan jika berbicara selalu terus terang. 4 orang mengatakan tidak suka terburu dalam melakukan sesuatu, 3 orang mengatakan selalu dalam menunggu suatu hal, 3 orang mengatakan tidak suka dengan persaingan, 3 orang mengatakan selalu melakukan sesuatu tanpa memaksakan diri, 3 orang mengatakan tidak bisa mengerjakan 2 hal dalam waktu bersamaan, 2 orang mengatakan sulit berterus terang dalam berbicara karena takut menyakiti perasaan orang dan 4 orang mengatakan jika melakukan sesuatu selalu menyesuaikan dengan kemampuan.

Untuk kualitas tidur 10 pasien hipertensi setelah dilakukan wawancara didapatkan bahwa 6 dari 10 orang memiliki kualitas tidur buruk dan 4 orang memiliki kualitas tidur baik. Data pasien hipertensi di UPT Griya Antapani pada Bulan November 2016 yaitu sebanyak 179 pasien hipertensi. Jumlah pasien hipertensi di UPT Griya Antapani merupakan yang terbanyak dari jumlah pasien hipertensi di puskesmas-puskesmas sekitarnya.

Berdasarkan permasalahan diatas maka peneliti merasa perlu melakukan penelitian tentang "Hubungan Kualitas Tidur dan Tipe Kepribadian Dengan
Tekanan Darah pada Pasien Hipertensi di UPT Griya Antapani Kota Bandung”.

\section{METODE PENELITIAN}

Jenis penelitian yang digunakan dalam penelitian ini adalah deskriptif korelasi dengan menggunakan pendekatan cross sectional. Dalam penelitian ini diteliti mengenai "Hubungan Kualitas Tidur dan Tipe Kepribadian Dengan Tekanan Darah Pada Pasien Hipertensi di UPT Griya Antapani Kota Bandung”. Teknik pengambilan sampel dalam penelitian ini purposive sampling dengan Kriteria Inklusi: 1) Pasien Hipertensi di UPT Griya Antapani Kota Bandung 2). Berusia 18 45 tahun 3). Bersedia menjadi responden 4). Mampu berkomunikasi secara verbal 5).Tidak memiliki riwayat penyakit DM, dan kriteria Eklusi: 1) Tidak bersedia menjadi responden 2). Tidak bisa membaca 3). Memiliki hipertensi berat. Berdasarkan kriteria inklusi dan eksklusi tersebut, dari total 179 pasien hipertensi di UPT Griya Antapani Kota Bandung didapatkan 54 sampel pasien hipertensi yang sesuai dengan kriteria tersebut. 


\section{HASIL DAN PEMBAHASAN}

1. Tekanan darah pasien hipertensi di UPT Griya Antapani Kota Bandung

\section{Tabel 1}

Tekanan darah pasien hipertensi di UPT Griya Antapani Kota Bandung

\begin{tabular}{rrr}
\hline & Frequency & Percent \\
\hline Ringan & 26 & 48,1 \\
Sedang & 28 & 51,9 \\
Total & 54 & 100,0 \\
\hline
\end{tabular}

Tabel tersebut menunjukan sebagian besar atau 28 orang $(51,9 \%)$ mengalami hipertensi sedang di UPT Griya Antapani Kota Bandung. Menurut Potter \& Perry (2010) tekanan darah yaitu kekuatan lateral pada dinding arteri oleh darah yang didorong dengan tekanan dari jantung. Tekanan darah timbul ketika darah bersikulasi di dalam pembuluh darah.

Menurut RISKESDAS 2007 bahwa didapatkan prevalensi hipertensi pada penduduk usia 18 tahun ke atas cukup tinggi mencapai 31,7 \% (Candradewi \& Sudhana, 2014). Usia merupakan salah satu faktor yang mempengaruhi tekanan darah. Usia berkaitan dengan tekanan darah tinggi (hipertensi). Semakin tua seseorang maka semakin besar resiko terserang hipertensi (Khomsan, 2003 dalam Novitaningtyas, 2014). Sampel dalam penelitian ini adalah pasien hipertensi dengan batasan usia $18-45$ tahun. Hasil penelitian didapatkan bahwa di UPT Griya Antapani penderita hipertensi terbanyak pada usia $36-45$ tahun. Menurut peniliti hal ini dapat disebabkan karena usia 36 - 45 adalah usia dewasa akhir dimana pada usia tersebut tingkat kesibukan sangat tinggi sehingga dapat memicu terjadinya stress yang dapat merangsang kelenjar adrenal untuk mensekresi epineprin yang menyebabkan vasokontriksi pembuluh darah sehingga tekanan dalam pembuluh darah meningkat dan ahirnya menyebabkan hipertensi.

2. Kualitas tidur pasien hipertensi di UPT Griya Antapani Kota Bandung

\section{Tabel 2}

Kualitas tidur pasien hipertensi di UPT Griya Antapani Kota Bandung

\begin{tabular}{|c|c|c|}
\hline & Frequency & Percent \\
\hline Baik & 12 & 22,2 \\
\hline buruk & 42 & 77,8 \\
\hline total & 54 & 100,0 \\
\hline
\end{tabular}

Tabel tersebut menunujukan hampir seluruh atau 42 orang $(77,8 \%)$ mengalami kualitas tidur buruk di UPT Griya Antapani Kota Bandung. Hasil penelitian ini sejalan dengan penelitian yang dilakukan oleh Angkat (2009) pada remaja siswa di SMA Tanjung Morawayang mengungkapkan bahwa $76,7 \%$ reponden mengalami kualitas tidur yang buruk. Demikian juga dengan penelitian yang dilakukan oleh Manalu, Bebasari dan Butar (2012) yang melakukan penelitian tentang kualitas tidur pada mahasiswa Fakultas Kedokteran Universitas Riau dari 
hasil penelitian tersebut didapatkan mayoritas responden memiliki kulitas tidur yang buruk yaitu (84\%).

Menurut peneliti kualitas tidur buruk dapat mempengaruhi tekanan darah karena dapat merangsang saraf simpatis bekerja terus menerus yang akan menyebabkan vasokontriksi pembuluh darah sehingga terjadi peningkatan tekanan darah. Apabila terjadi peningkatan tekanan darah secara terus menerus maka akan menyebabkan hipertensi.

3. Tipe kepribadian pasien hipertensi di UPR Griya Antapani Kota Bandung

Tabel 3

Tipe kepribadian pasien hipertensi di UPT Griya Antapani Kota Bandung

\begin{tabular}{cccr}
\hline & & Frequency & Percent \\
\hline Tipe & A & 28 & 51,9 \\
Tipe & B & 26 & 48,1 \\
total & & 54 & 100,0 \\
\hline Hasil & penelitian & yang & dilakukan
\end{tabular}

didapatkan bahwa sebagian besar responden yaitu 28 orang $(51,9 \%)$ memiliki kepribadian tipe A. Menurut peneliti hal tersebut dapat terjadi karena responden dalam penelitian ini merupakan pasien hipertensi. Tipe kepribadian berpengaruh terhadap kekambuhan hipertensi karena dilihat dari cara seseorang menggunakan koping stressnya. Berbagai faktor seperti emosi, kecemasan dan ketakutan dapat mempengaruhi respon pembuluh darah terhadap rangsang vasokonstriksi sehingga meningkatkan tekanan darah.

4. Hubungan kualitas tidur dengan tekanan darah pada pasien hipertensi di UPT Griya Antapani Kota Bandung

Tabel 4

Hubungan kualitas tidur dengan tekanan darah pada pasien hipertensi di UPT Griya Antapani Kota Bandung

\begin{tabular}{lcccc}
\hline & \multicolumn{2}{c}{ Tekanan darah } & & \\
\cline { 2 - 4 } Kualitas tidur & HT ringan & HT sedang & Total & P Value \\
\hline Baik & 12 & 0 & 12 & \\
Buruk & 14 & 28 & 42 & 0,000 \\
Total & 26 & 28 & 54 & \\
& & &
\end{tabular}

Tabel di atas menunjukan hubungan kualitas tidur dengan tekanan darah pada pasien hipertensi di UPT Griya Antapani Kota Bandung. Hasil analisis hubungan kualitas tidur dengan tekanan darah pada pasien hipertensi diperoleh bahwa ada hubungan kualitas tidur dengan tekanan darah pada Pasien hipertensi. Hal ini 
karena $\mathrm{p}$ value $(0,000)<\alpha(0,05)$. Artinya terdapat hubungan yang signifikan antara kualitas tidur dengan tekanan darah pada pasien hipertensi.

Kualitas tidur yang buruk berhubungan dengan meningkatnya resiko hipertensi dan dengan demikian akan meningkatkan resiko penyakit kardiovaskular. Menurut penelitian J.E Gangswich menyatakan bahwa apabila terjadi kekurangan waktu tidur akan secara akut menaikan tekanan darah dan mengaktivasi sistem saraf simpatis yang dalam jangka waktu lama hal tersebut akan memicu terjadinya hipertensi.

Menurut peneliti kualitas tidur yang buruk mampu mempengaruhi tekanan darah seseorang karena terjadi perangsangan saraf simpatis yang dapat meningkatkan tekanan darah secara terus menerus. Apabila hal tersebut berlangsung lama dapat mengakibatkan hipertensi.

5. Hubungan tipe kepribadian dengan tekanan darah pada pasien hipertensi di UPT Griya Antapani Kota Bandung

Tabel 5

\section{Hubungan tipe kepribadian dengan tekanan darah pada pasien hipertensi di UPT Griya Antapani Kota Bandung}

\begin{tabular}{cccccc}
\hline Tipe kepribadian & \multicolumn{2}{c}{ Tekanan darah } & & P Value \\
\cline { 2 - 3 } & HT ringan & HT sedang & Total & \\
\hline Tipe A & 0 & 28 & 28 & \\
Tipe B & 26 & 0 & 26 & 0,000 \\
Total & 26 & 28 & 54 & \\
\hline
\end{tabular}

Pada tabel 5 di atas menunjukan hubungan tipe kepribadian dengan tekanan darah pada pasien hipertensi di UPT Griya Antapani Kota Bandung menunjukan bahwa ada hubungan tipe kepribadian dengan tekanan darah pada pasien hipertensi. Hal ini karena p value $(0,000)$ $<\alpha(0,005)$. Artinya terdapat hubungan yang signifikan antara tipe kepribadian dengan tekanan darah pada pasien hipertensi.

Penelitian yang dilakukan oleh Yosefin dan Wahyu (2011) tentang hubungan kepribadian tipe A dengan kejadian hipertensi di RSUD Prof. Dr. Margono Soekardjo menunjukan terdapat hubungan yang signifikan antara tipe A dengan kejadian hipertensi. Sejalan dengan penelitian yang dilakukan oleh Chitrayana, dkk (2012) tentang kepribadian tipe A dan risiko hipertensi pada orang dewasa didapatkan hasil bahwa risiko hipertensi lebih besar secara bermakna 1,3 kali pada responden dengan kepribadian tipe A dibandingkan dengan responden berkepribadian tipe $\mathrm{B}$. 
Menurut peneliti tipe kepribadian sangat mempengaruhi tekanan darah karena dilihat dari cara seseorang menggunakan koping stressnya. Karena stress dapat mempengaruhi respon pembuluh darah menjadi vasokontriksi sehingga menyebabkan tekanan darah meningkat.

\section{SIMPULAN}

Berdasarkan penelitian tersebut dapat disimpulkan bahwa sebagian besar atau 28 orang $(51,9 \%)$ responden di UPT Griya Antapani Kota Bandung mengalami hipertensi sedang. Hampir seluruh atau 42 orang $(77,8 \%)$ responden di UPT Griya Antapani Kota Bandung mengalami kualitas tidur buruk. Sebagian besar atau 28 orang $(51,9 \%)$ responden di UPT Griya Antapani Kota Bandung memiliki kepribadian tipe A. Terdapat hubungan kualitas tidur dengan tekanan darah pada pasien hipertensi di UPT Griya Antapani Kota Bandung. Hal ini karena $\mathrm{p}$ value $(0,000)<\alpha(0,05)$. Terdapat hubungan tipe kepribadian dengan tekanan darah pada pasien hipertensi di UPT Griya Antapani Kota Bandung. Hal ini karena $\mathrm{p}$ value $(0,000)<\alpha(0,05)$.

\section{DAFTAR PUSTAKA}

Albert, 2012. Hubungan Antara Kualitas Tidur Dengan Tekanan Darah Pada Mahasiswa Fakultas Kedokteran Universitas Sumatera Utara Tahun
Masuk 2009, Medan: Fakultas Kedokteran Universitas Sumatera Utara. Amir. 2007. Gangguan Tidur pada Lanjut Usia. FKUI: Jakarta

Anggraini, dkk. (2009). Faktor--Faktor yang Berhubungan Dengan Kejadian Hipertensi Pada Pasien Yang Berobat Di Poliklinik Dewasa Puskesmas Bangkinang Periode Januari Sampai Juni 2008. Pekanbaru Riau : Faculty of Medicine-University of Riau

Arikunto, S. 2010. Prosedur Penelitian Suatu Pendekatan Praktek. Edisi Revisi V. Jakarta: PT Rineka Cipta

Asmadi. 2008. Konsep dan Aplikasi Kebutuhan Dasar Klien. Jakarta: Salemba Medika.

Asmarita, Intan. 2014. Hubungan Antara Kuallitas Tidur Dengan Tekanan Darah Pada Pasien Hipertensi Di Rumah Sakit Umum Daerah Karanganyar, Surakarta: Fakultas Kedokteran Universitas Muhammadiyah Surakarta.

Baharudin, Kurdi FN, Lionardo A. Analisis Perbedaan Tipe Kepribadian A dan B Manajemen Konflik Interpersonal Pada Pegawai Rumah Sakit Khusus Mata Provinsi Sumatera Selatan. Jurnal Psikologi Islami. Vol. 1 No. 2 (2015) 25-33

Black, J. M. \& Hawks, J. H. 2014. Keperawatan Medikal Bedah Edisi 8. Singapura:Elsevier.

Candradewi ND \& Sudhana W. Prevalensi Penyakit Hipertensi Pada Usia Dewasa Muda Di Wilayah Kerja Puskesmas Abang 1 Periode Januari 2014, Karangasem: Fakultas Kedokteran, Universitas Udayana

Chitrayana N, Feby B, Lauren Y, Rumawas ME, Kidarsa VB. 2012. Kepribbadian Tipe A dan Risiko Hipertensi pada Orang Dewasa, Jakarta: Fakultas Kedokteran, Universitas Tarumanegara

DepKes. 2012. Propil Kesehatan Provinsi Jawa Barat. http://www.depkes.go.id/resources/dow nload/profil/PROFIL_KES_PROVINSI 2012/12_Profil_Kes.Prov.JawaBarat_2 012.pdf. Diakses Pada 18 Desember 2016 Pukul 00.00

Fitri, AA. 2013. Hubungan Kualitas Tidur Dengan Kejadian Hipertensi, Jakarta: Fakultas Kedokteran dan Ilmu 
Kesehatan, Universitas Islam Negeri Syarif Hidayatullah.

Hidayat AA. 2009. Kebutuhan dasar manusia. Jakarta: Salemba Medika

Hidayat, A. 2008. Pengantar Kebutuhan Dasar Manusia Aplikasi Konsep dan Proses Keperawatan. Jakarta: Salemba Medika.

James E Gangswich, et al. Short sleep duration as a risk factor hypertension Circulation AHA Journal. 2006;47:833-839

Jurnal Kesehatan. 2010. Tipe Kepribadian A dan $B$ menurut Friedman dan Rosenman.

Kozier, B \& Erb, G. 2009. Buku Ajar Praktik Keperawatan Klinis, Edisi 5. Jakarta: EGC.

Lloyd-Jones, et al. (2010). Heart disease and stroke statistics update: a report from the American Heart Association. Circulation.; Vol 2 No 1 : 121-146

Magfirah, Inun. 2016. Hubungan Kualitas tidur dengan Tekanan Darah Pada Mahasiswi Program Studi SI Fisioterapi Angkatan 2013 dan 2014 di Universitas Hasanuddin, Makasar: Fakultas Kedokteran, Universitas Hasanuddin

Notoatmodjo, Soekidjo. 2012 Metodologi Penelitian Kesehatan. Jakarta: Rineka Cipta

Novitaningtyas, T. 2014. Hubungan Karateristik (Umur, Jenis Kelamin, Tingkat Pendidikan, Dan Aktivitas Visik) Dengan Tekanan Darah Pada Lansia di Kelurahan Makamhaji Kecamatan Kartasura Kabupaten Sukoharjo, Surakarta: Fakultas Ilmu Kesehatan, Universitas Muhammadiyah

Nursalam. 2009. Konsep dan Penerapan Metodologi Penelitian Ilmu Keperawatan. Jakarta: Salemba Medika

Potter, P. A \& Perry, A. G. 2010. Buku Ajar Fundamental Kepeerawatan: Konsep, Proses dan Praktik Volume I Edisi 4. Jakarta: EGC.

Ratnaningtyas Y \& Djatmiko W. HUBUNGAN KEPRIBADIAN TIPE D
DENGAN KEJADIAN HIPERTENSI DI

RSUD PROF. DR. MARGONO SOEKARDJO. Mandala of Health. Volume 5. Nomor 2, Mei 2011

Risnasari, Norma. 2012. Gambaran Tipe Kepribadian Penderita Hipertensi di Poli dalam RSUD Gambiran Kota Kediri, Kediri: Fakultas Ilmu Kesehatan, Universitas Nusantara PGRI.

Saleh S, Basmanelly \& Huriani E. Hubungan Tingkat Stres Derajat Hipertensi Pada Pasien Hipertensi Di Wilayah Kerja Puskesmas Andalas Padang Tahun 2014. Ners Jurnal Keperawatan Volume 10. No 1, Oktober 2014: 166 - 175

Riyadi S, Widuri H. 2015. Kebutuhan Dasar Manusia Aktivitas Istirahat Diagnosis Nanda. Yogyakarta: Gosyen Publishing. Septiyani RD, 2010. Pengaruh Tipe Kepribadian Dengan Derajat Hipertensi Pada Pasien Hipertensi Wanita Usia 30-50 Tahun Di Puskesmas Gilingan Surakarta, Surakarta: Fakultas Ilmu Kesehatan Universitas Muhammadiyah

Sjarkawi, (2008). Pembentukan Kepribadian. Jakarta : Bumi Aksara

Tilong AD. Waspada!!! Penyakit-Penyakit Mematikan Tanpa Gejala Menyolok (Jogjakarta: Buku Biru, 2014), hlm. 91.

Widyastuti, Yuni. 2015. Hubungan Antara Kualitas Tidur Lansia Dengan Tingkat Kekambuhan Pada Pasien Hipertensi di Klinik Dhanang Husada Sukoharjo, Surakarta: Program Studi S-1 Keperawatan, STIKes Kusuma Husada.

Yaqin UFN. 2016. Hubungan Kualitas Tidur Dengan Tekanan Darah Pada Mahasiswa Program Studi Ilmu Keperawatan, Jember: Program Studi Ilmu Keperawatan, Universitas Jember.

Yasinta IN. 2009. Hubungan antara kepribadian dengan hipertensi, Malang: Fakultas Ilmu Pendidikan, Universitas Negeri 